\title{
Metal Sorption Capabilities of Two Common Plants in Tropical Wetlands - Bambusa vulgaris and Raffia bambusa*
}

\author{
${ }^{1}$ G. Ofori-Sarpong, ${ }^{2}$ R. K. Asamoah, ${ }^{1}$ J. J. K. Gordon and ${ }^{1}$ R. K. Amankwah \\ ${ }^{1}$ University of Mines and Technology, P.O. Box 237, Tarkwa, Ghana \\ ${ }^{2}$ University of South Australia, Mawson Lakes SA 5095 Australia
}

Ofori-Sarpong, G., Asamoah, R. K., Gordon, J. J. K. and Amankwah, R. K. (2016), "Metal Sorption Capabilities of Two Common Plants in Tropical Wetlands - Bambusa vulgaris and Raffia bambusa", Ghana Mining Journal, Vol. 16, No. 2, pp. 73 - 80.

\begin{abstract}
In most developing countries, careless disposal of waste dry cell batteries and Ni-Cd batteries from mobile phones and rechargeable lamps has led to an increase in some metal contaminants including copper, lead, nickel and cadmium in soils and water bodies. These metals have the potential to cause serious, and sometimes, irreversible health effects if they are consumed. Unfortunately, in most cases, either the water bodies are not treated prior to consumption or the water treatment methods do not target the removal of these metals. This study therefore sought to mimic the bio-filtering effect of wetlands by assessing the capabilities of two common plants in tropical wetlands; Raffia bambusa and Bambusa vulgaris to remove $\mathrm{Cu}^{2+}, \mathrm{Pb}^{2+}, \mathrm{Ni}^{2+}$ and $\mathrm{Cd}^{2+}$ from wastewater. Spectroscopic characterisation indicated that some of the functional groups on the biomass were the $\mathrm{OH}, \mathrm{C}=\mathrm{O}$ and $\mathrm{COOH}$, and $R$. bambusa appeared to have more pronounced groups than B. vulgaris. The results show maximum sorption of $95 \% \mathrm{Cu}$ and $\mathrm{Pb}$ by biomass derived from roots of these plants. Sorption of $\mathrm{Cd}$ and $\mathrm{Ni}$ were lower at about $40 \%$. By using a 3 -stage sorption system of live plants, sorption of $\mathrm{Cd}$ and $\mathrm{Ni}$ increased up to $80 \%$.
\end{abstract}

Keywords: Heavy Metals, Sorption, Biomass, Bambusa vulgaris, Raffia bambusa

\section{Introduction}

The increase in metal ion concentration in the environment due to technological advancement has been an issue of major concern (Ehrlich and Brierley, 1990; Volesky, 1990; Glazer and Nikaido, 1995; Volesky and Holan, 1995; Ehrlich, 1997; Tsezos, 2001; Volesky, 2001; Amankwah and Yen, 2005). Toxic/heavy metal-contaminated waste may be generated from anthropogenic activities such as mining, smelting, electroplating and manufacturing operations among others. Another major source is improper recycling of electronic waste (e-waste).

In a study conducted by Anon (2010), e-waste was found to be the fastest growing component of municipal waste, with the total annual global volume approaching 40 million metric tonnes. Ewaste generally contains substantial amounts of heavy/toxic metals including lead, cadmium, nickel, chromium, copper, mercury and arsenic (Man et al., 2013). Waste recycling methods such as burning, melting, chopping and acid digestion may lead to release of a wide range of toxic chemicals which add to the concentration of heavy metals in the environment (Terazono et al., 2006).

Ghana, like most developing countries, is gradually becoming a dumping ground for e-waste, and Agbogbloshie market in Accra has become a major site for recycling such waste (Asante et al, 2012; Oteng-Ababio, 2012; Itai et al, 2014; OtengAbabio et al, 2014). Studies by these researchers show that metals and metalloids associated with ewaste such as lead, mercury, arsenic, cadmium, selenium, chromium and copper are accumulating in soils, water bodies and even in the tissues of workers who recycle such materials. In Ghana, since domestic/municipal wastewater is generally not treated, these metals when solubilised may be transported from the point of generation and affect communities downstream.

Another scenario that increases the metal ion concentration in the environment is careless disposal of metal components due to less stringent environmental enforcement of recycling methods. For example, the problem of unreliable power supply from national grids has resulted in increasing usage of battery-powered lamps in households and offices. In addition, there is a geometric increase in the use of mobile phones (Kochi, 2012; Fortin, 2013). These units are mostly powered by $\mathrm{Ni}-\mathrm{Cd}$ rechargeable batteries and dry cells, and careless disposal of these batteries has led to an increase in the presence of lead, nickel and cadmium in surface and ground waters (Volesky, 2001). The solubility and mobility of these metals, and possible accumulation and retention throughout the food chain, leads to serious ecological and health hazards to both flora and fauna (Gupta and Ali, 2004; Iyer et al, 2005; Bayo et al., 2009; Ibrahim, 2011; Areco et al, 2012). 
There is thus an urgent need to process wastewaters before discharge into the general environment. In addition, remediation of contaminated water bodies should also be investigated. Available technologies include ion exchange, reverse osmosis, electrochemical reduction, membrane technology, chemical precipitation, adsorption on activated carbon, solvent extraction and biosorption (Volesky and Holan, 1995; Volesky, 2001; Davis et al., 2003; Bayo et al., 2009).

Biosorption focuses on the metal binding capacities of various plants and lower animals. In recent times, biosorption has become a preferred method for metal decontamination, especially when dealing with contaminants of dilute solutions. This is because it presents a technically simple and economically viable alternative to the abiotic processes (Glazer and Nikaido, 1995; Volesky and Holan, 1995; Hawari and Mulligan, 2006; Ahluwalia and Goyal, 2007; Fu and Wang, 2011).

Biosorption may be accomplished in natural systems or by the use of treated biomass. In the natural environment, wetlands play a dominant role. Wetlands act as biofilters, and combines phytoremediation with microbial activity (Park et al., 2011). They also serve as a cheaper alternative to chemical processes in metal immobilisation (Yong et al., 2006).

Preliminary studies in some parts of Ghana by the authors showed a consistent increase in the concentration of nickel, cadmium, lead and copper in water bodies, partly due to careless disposal of waste batteries and other electronic wastes (Asamoah et al., 2012). If not checked, this development has the potential to pollute both surface and ground waters and also affect biotic organisms. The increase in concentrations of these metal ions is especially pronounced in small-scale gold mining environments where the miners use these batteries to power lamps for night duties and underground operations. In such areas, also, land disturbance exposes sulphide minerals which undergo oxidation leading to acid generation and reduction of the $\mathrm{pH}$ of some surface waters to between 5 and 6 . These acidic waters enhance solubilisation of metals from the waste electronic components after they have been discharged indiscriminately in the environment.

Unfortunately, normal pipe-borne water treatment procedures may not target these metals, and in some cases, the water may not even be treated before domestic consumption. It is therefore imperative to source treatment methods that are technically simple, economically viable, readily available, and environmentally friendly.

Surface waters usually encounter plants as they flow in their courses and/or pass through wetlands.
Some plants such as Bambusa vulgaris and Raffia bambusa are common in tropical wetlands, and may contribute to the removal of dissolved metals. However, the metal sorption capabilities of these plants are yet to be documented. This paper therefore sought to mimic the metal-filtering ability of wetlands by using the roots of $B$. vulgaris and $R$. bambusa as biosorbents for the sequestration of $\mathrm{Cd}$, $\mathrm{Pb}, \mathrm{Ni}$ and $\mathrm{Cu}$. The aim was to ascertain if such plants can be incorporated into contaminated water bodies to enhance natural purification before the water is used domestically, especially in areas where there is no pipe-borne water.

\section{Resources and Methods Used}

\subsection{Materials}

The roots of B. vulgaris and R. bambusa (Fig. 1) were harvested from wetlands in south-western Ghana. In the first approach, the roots were washed thoroughly with de-ionized water, air-dried, and then cut to sizes between 4.0 and $2.0 \mathrm{~mm}$. The dry weight of the biomass was determined after drying at $70^{\circ} \mathrm{C}$. In the second approach, live plants were used after washing to get rid of soil. Artificial wastewater containing multiple metal ions; $\mathrm{Cd}, \mathrm{Pb}$, $\mathrm{Ni}$ and $\mathrm{Cu}$ with concentrations, $10 \mathrm{ppm}, 50 \mathrm{ppm}$, $100 \mathrm{ppm}$ was prepared by dissolving appropriate quantities of cadmium chloride, lead nitrate, nickel sulphate and copper sulphate respectively in distilled water.
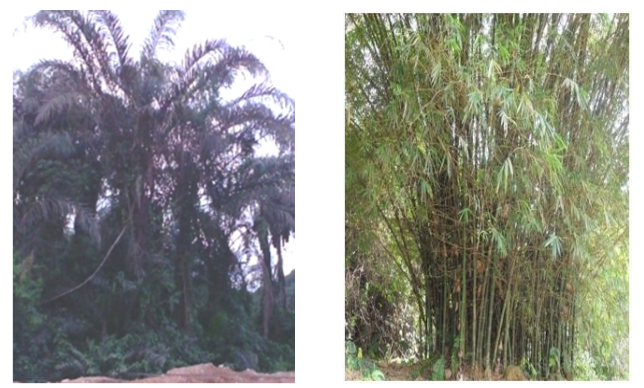

Fig. 1 Raffia bambusa (a) and Bambusa vulgaris (b)

\subsection{Methods}

\subsubsection{Biomass-Metal Ion Interactions}

The roots of $B$. vulgaris and $R$. bambusa were brought into contact with $250 \mathrm{ml}$ of artificial wastewater in 500-ml Erlenmeyer flasks, and the flasks were agitated at a low rate of $80 \mathrm{rpm}$ using an MRC incubator shaker for up to 180 minutes at $25^{\circ} \mathrm{C}$. Three biomass concentrations of $0.1,0.5$ and $1.0 \mathrm{~g} / \mathrm{L}$ were prepared to examine the effect of biomass concentration on biosorption. After an adsorption cycle of up to 180 minutes, the biomass was separated by filtration, and the metal ion concentration in the aqueous phase was determined using Varian AA240FS Atomic Absorption Spectrometer. 
Following investigations with dry chips, further experiments with live plants were also conducted. A 3-stage sorption system was set up with 3 vases and wastewater was contacted with live biomass. The wastewater was allowed to flow from one stage to the other (Fig. 2), and the solution samples exiting each stage after the expected retention time were analysed. The solution was allowed to flow through by gravity at a flow rate of $20 \mathrm{ml} / \mathrm{min}$ to ensure good contact between biomass and wastewater. The flow rate allowed a retention time of $6 \mathrm{~h}$ per stage and $21.6 \mathrm{~L}$ of wastewater was treated altogether. The wet mass of the plants was $500 \mathrm{~g} \pm 20 \mathrm{~g}$.

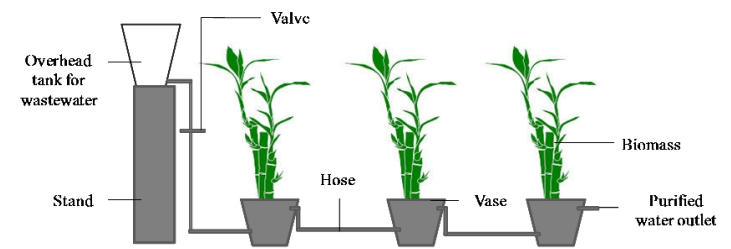

Fig. 2 Set-up for 3-stage Process (Sketch of Bamboo Obtained by Courtesy of Openclipart.org)

In all experiments, the $\mathrm{pH}$ was kept at $5.4 \pm 0.2$ by the addition of dilute nitric acid or sodium hydroxide. This is because biosorption is affected by changes in $\mathrm{pH}$ due to changes in the dissociation of functional groups present on the surface of the biomass. At low $\mathrm{pH}$ values, there is excessive protonation of the active sites and hence competition between hydrogen ions and other metal ions for the same sites leading to a reduction in sorption rate. In addition, metal ion precipitation may also occur at $\mathrm{pH}$ values above 6.0 (Fourest and Roux, 1992; Fourest and Volesky, 1996).

\subsubsection{Fourier Transform-Infrared Spectroscopy of Biomass}

The functional groups on the dry biomass were determined by Fourier transform infrared analysis using a Bomen Grams/32 Spectrometer. Pulverised biomass was mixed with $\mathrm{KBr}$ in a ratio of $1: 150$ and the spectra were recorded between 700 and $4000 \mathrm{~cm}^{-1}$. The axes of each spectra were normalised to facilitate comparison.

\subsubsection{Calculation of Percent Metal Removal and Root Sorption Capacity}

At the end of the biosorption experiments, the residual metal ion concentration $\mathrm{Ce}$ and the initial metal ion concentration $\mathrm{Co}$ were utilised in estimating the metal sorbed by the biomass, $\mathrm{R}$ (Equation 1).

$$
\mathrm{R}=\left(\frac{\mathrm{C}_{\mathrm{o}}-\mathrm{C}_{\mathrm{e}}}{\mathrm{C}_{\mathrm{o}}}\right) \times 100 \%
$$

The sorption capacity, $\mathrm{q}$ ( $\mathrm{mg}$ of metal/g of biomass), of the biosorbents was determined using Equation 2:

$$
\mathrm{q}=\mathrm{V}\left(\mathrm{C}_{\mathrm{o}}-\mathrm{C}_{\mathrm{e}}\right) / \mathrm{W}
$$

where $\mathrm{V}$ is the volume of solution (L) and $\mathrm{W}$ is dry weight of biomass $(\mathrm{g})$.

\section{Results and Discussion}

\subsection{Spectroscopic Characterisation of Biomass}

Some studies using biomass for sorption of toxic/heavy metals attribute sequestration to the presence of functional groups on the biomass that interact with the metal ions. Thus the spectrographic characterisation was done to identify such groups. The spectrographs of both biomasses are shown in Fig. 3. The peak assignments are based on data provided by Faix (1992) and Boeriu et al (2004).

The peak between 3350 and $3320 \mathrm{~cm}^{-1}$ is from the presence of $\mathrm{OH}$ groups and generally attributed to the presence of water. Boeriu et al (2004) also ascribed the $\mathrm{OH}$ groups to phenolic and aliphatic structures associated with lignin. The bands centered around 2900, 1620 and $1460 \mathrm{~cm}^{-1}$ are predominantly for $\mathrm{CH}_{2}$ and $\mathrm{CH}_{3}$, and that at 1100 $\mathrm{cm}^{-1}$ is due to the $\mathrm{COOH}$ group. Other peaks were detected at $1705-1720 \mathrm{~cm}^{-1}$ which are associated with the $\mathrm{C}=\mathrm{O}$ group. Boeriu et al (2004) attributed the band at 1370-1375 to phenolic $(\mathrm{OH})$ and aliphatic $\mathrm{C}-\mathrm{H}$ in methyl groups and the peak assignment at $1220 \mathrm{~cm}^{-1}$ can be ascribed to C-C, C$\mathrm{O}$ and $\mathrm{C}=\mathrm{O}$ groups.

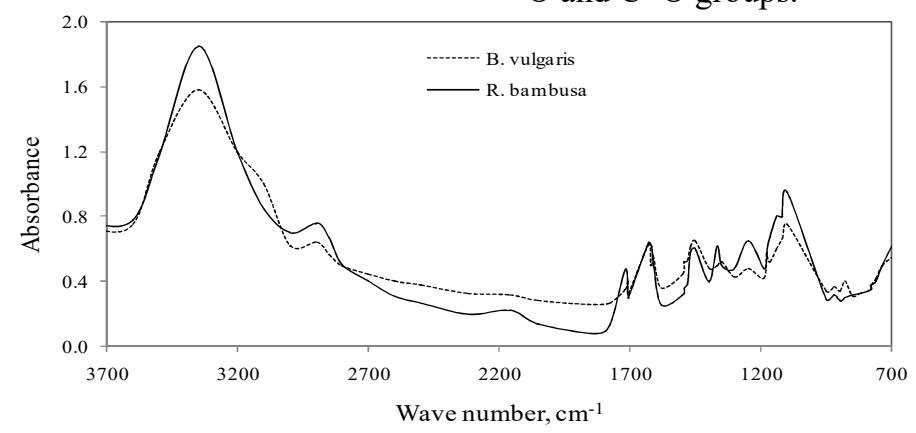

Fig. 3 Infrared Spectrograph of $R$. bambusa and B. vulgaris 
It can be seen that both biomass showed similar spectra. However the absorbance at some wave numbers such as between 3350 and 3320 and around 2900, 1220-1250 and $1100 \mathrm{~cm}^{-1}$ were higher for $R$. bambusa than for $B$. vulgaris. Thus it could be deduced that $R$. bambusa had more pronounced $\mathrm{C}=\mathrm{O}, \mathrm{COOH}, \mathrm{CH}_{2}$ and $\mathrm{CH}_{3}$ groups.

\subsection{Wastewater - Dry Biomass Interactions}

Fig. 4 shows the sorption curve for copper when the wastewater was contacted with both $R$. bambusa and $B$. vulgaris at various biomass concentrations. For all biomass concentrations, $R$. bambusa proved to be a better adsorber than $B$. vulgaris. From an initial copper ion concentration of $100 \mathrm{ppm}, 0.1 \mathrm{~g} / \mathrm{L} R$. bambusa reduced the copper concentration by $55 \%$ within 15 minutes, $70 \%$ after 60 minutes, and $85 \%$ after 180 minutes. In a similar manner, $1.0 \mathrm{~g} / \mathrm{L} R$. bambusa reduced copper ion concentration by $70 \%$ after 15 minutes and 91\% after 180 minutes. This indicates that the metal ion has been sequestered, possibly by some surface functional groups such as the carbonyl, and carboxylic acids on the biomass (Fig. 3).

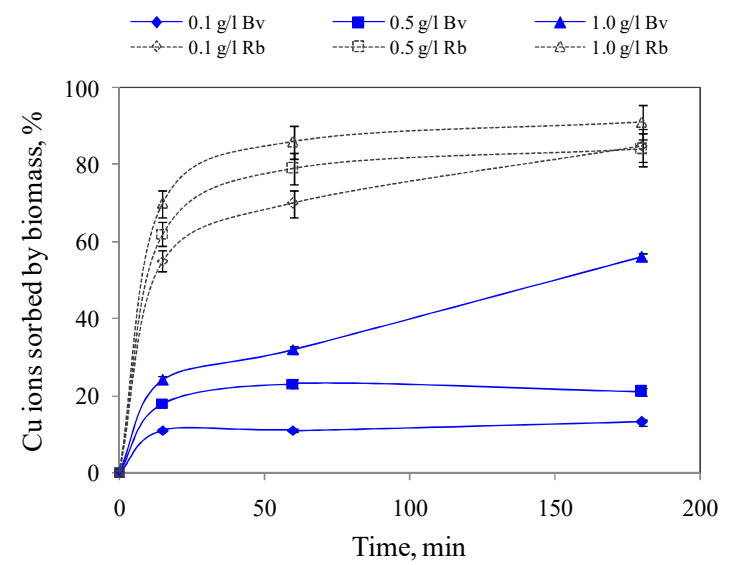

Fig. 4 Sorption of $\mathrm{Cu}$ on $B$. vulgaris (Bv) and $R$. bambusa (Rb) at various Biomass Concentrations. Initial $\mathrm{Cu}$ Concentration was 100 ppm

For $0.1 \mathrm{~g} / \mathrm{L}$ and $0.5 \mathrm{~g} / \mathrm{L}$ B. vulgaris, the residual copper ion values were quite high at $87 \mathrm{ppm}$ and 80 ppm respectively after 180 mins. The residual concentration, however, reduced with increased biomass concentration; for $1.0 \mathrm{~g} / \mathrm{L} \mathrm{B}$. vulgaris, as the residual copper ion concentration was $44 \mathrm{ppm}$, showing that more than $50 \%$ was sorbed. For $R$. bambusa, however, more than $80 \%$ of the metal ion was sorbed at all biomass concentrations.

The sorption curves for $\mathrm{Pb}$ ions were quite different from those for $\mathrm{Cu}$ as both $R$. bambusa and $B$. vulgaris sorbed higher concentrations of $\mathrm{Pb}$, above $65 \%$ (Fig. 5). From an initial $\mathrm{Pb}$ concentration of $100 \mathrm{ppm}$, sorption was very high within the initial 15 minutes and continued at a much slower rate until 180 minutes. With $R$. bambusa, final sorption values were above $90 \%$ at all biomass concentrations, with $1.0 \mathrm{~g} / \mathrm{L}$ achieving $99.5 \%$ metal sorption. Similar biosorption curves with a sharp initial sorption rate followed by a slow section have been reported in the literature (Volesky, 1994; Volesky and Holan, 1995; Chen and Yiacaumi, 1997).

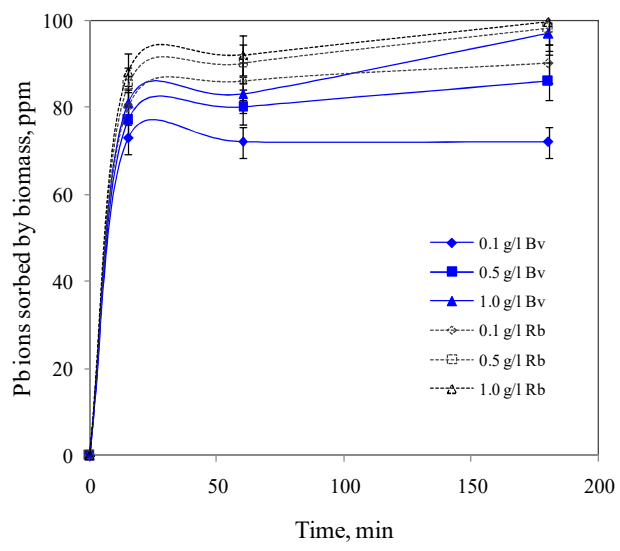

Fig. 5 Sorption of $\mathrm{Pb}$ on $B$. vulgaris $(\mathrm{Bv})$ and $R$. bambusa (Rb) at various Biomass Concentrations. Initial Pb Concentration was 100 ppm

Fig. 6 compares sorption of $\mathrm{Cu}$ and $\mathrm{Pb}$ by both biomass types from solutions of initial metal ion concentration of $10 \mathrm{ppm}$ and $0.1 \mathrm{~g} / \mathrm{L}$ biomass. The trend showed that most of the metal was sorbed quickly within the initial 15 minutes followed by a slow sorption process until 180 minutes. All samples showed some degree of metal ion reduction after the test period with a maximum of $90 \%$ for $\mathrm{Pb}$ using $R$. bambusa as sorbent. It is thus clear that when the initial metal ion concentration is lower, percentage sorption is higher.

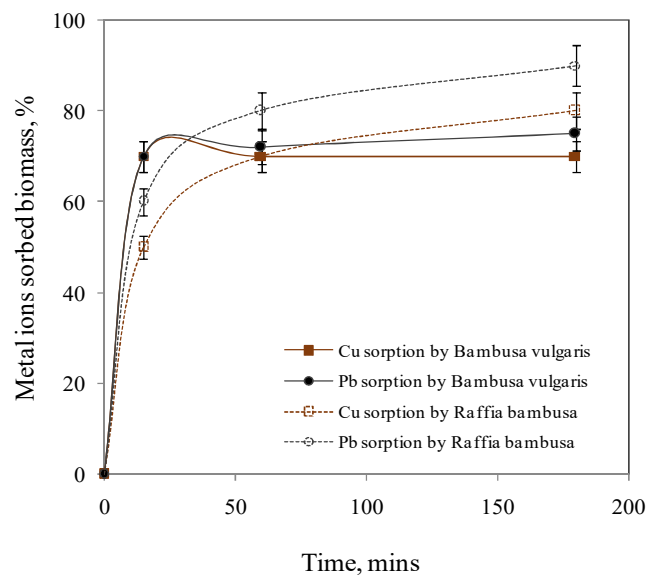

Fig. 6 Comparative Study of Sorption of $\mathrm{Cu}$ and Pb using $0.1 \mathrm{~g} / \mathrm{L}$ Concentrations of $B$. vulgaris and $R$. bambusa. Initial Concentration of $\mathrm{Cu}$ and $\mathrm{Pb}$ was 10 ppm

Fig. 7 shows that sorption of $\mathrm{Cd}$ and $\mathrm{Ni}$ by $B$. vulgaris was relatively low at $30 \%$ and $20 \%$ respectively after 15 minutes, and increased slightly 
to about $38 \%$ and $45 \%$ after 30 minutes. Beyond this period, the metal ions were desorbed into solution, and after 180 minutes, sorption was between 20 and $30 \%$ in both cases. This observation may be due to saturation of the active sites on the biomass. $R$. bambusa sorbed higher concentrations within the initial 15 minutes, and the curve shows desorption and re-adsorption of metal ions over the processing period, ending at about $45 \%$ sorption after $180 \mathrm{~min}$. Figs. 4-7 demonstrate that the two biomass types utilised have higher affinity for $\mathrm{Pb}$ and $\mathrm{Cu}$ than for $\mathrm{Cd}$ and $\mathrm{Ni}$.

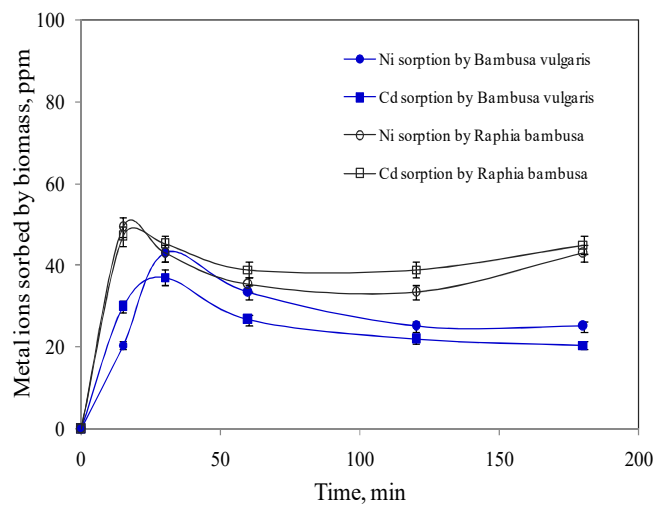

Fig. 7 Sorption of $\mathrm{Ni}$ and $\mathrm{Cd}$ by $\mathrm{B}$. vulgaris $(\mathrm{Bv})$ and $R$. bambusa (Rb). Initial Metal Ion and Biomass Concentrations were $100 \mathrm{ppm}$ and $1.0 \mathrm{~g} / \mathrm{L}$ Respectively

\subsection{Sorption capacity}

Figure 8 shows a plot of sorption capacity against initial metal ion concentration. The sorption capacities generally increased with increasing initial metal ion concentration. Taking the sorption of $\mathrm{Pb}$ by $B$. vulgaris, for example, as the initial $\mathrm{Pb}$ concentration was raised from $10 \mathrm{ppm}$ through 50 $\mathrm{ppm}$ to $100 \mathrm{ppm}$, the sorption capacity increased from 2.5 through 12.4 to $24.3 \mathrm{mg}$ of metal per gram of biomass. A similar trend was obtained for $\mathrm{Cu}$.

The sorption capacities of $\mathrm{Ni}$ and $\mathrm{Cd}$ onto $B$. vulgaris were quite low with a maximum value of 5 $\mathrm{mg} / \mathrm{g}$ at initial solution concentration of $100 \mathrm{ppm}$. For all the metal ions, sorption onto R. bambusa was higher by $3-40 \%$. The higher sorption capacity of $R$. bambusa may be attributed to the marked $\mathrm{C}=\mathrm{O}$ and $\mathrm{COOH}$ groups that are known to interact with and sequester metal ions (Volesky and Holan, 1995; Volesky, 2001).

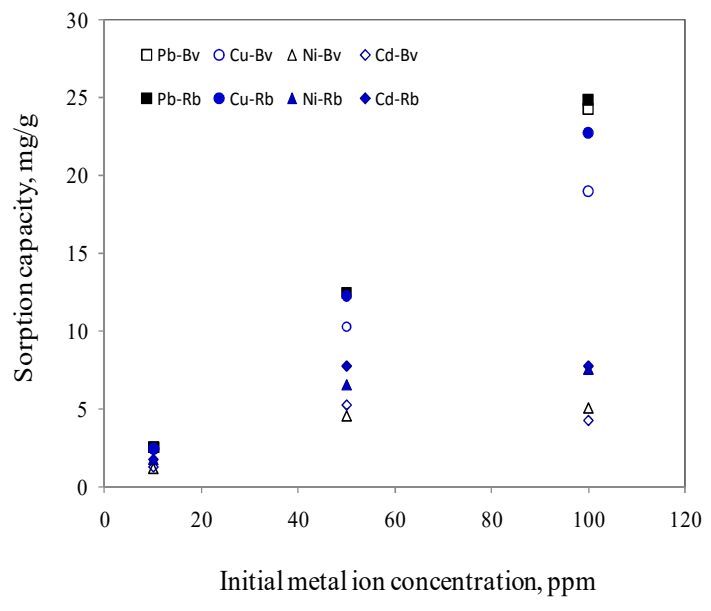

Fig. 8 Sorption Capacities of $\mathrm{Pb}, \mathrm{Cu}, \mathrm{Ni}$ and $\mathrm{Cd}$ by $B$. vulgaris (Bv) and R. bambusa $(\mathrm{Rb})$

In the literature, many researchers have attributed sorption preferences to the functional groups on the biomass to the charge and size of the ions being sorbed (Volesky, 1994; 2001). In this study, variations in the amount of metal sorbed may not be attributed to charge as all the metals have a charge of $+2 . \mathrm{Cu}^{2+}$ and $\mathrm{Ni}^{2+}$ ions are smaller than those of $\mathrm{Pb}^{2+}$ and $\mathrm{Cd}^{2+}$, thus size also did not play a dominant role.

\subsection{Sorption with Live Plants}

Following sorption studies with chips of dry biomass, further investigations were conducted using live biomass. Fig. 9, which illustrates the sorption profile, shows that there was a consistent reduction in metal ion concentration from one stage to the next. This may be attributed to contact between wastewater and fresh biomass with more active sorption sites. For $\mathrm{Cu}$ and $\mathrm{Pb}$, there were sharp drops in concentration in the initial stage, and there was further reduction till the concentration dropped below $0.05 \mathrm{ppm}$ by the end of the third stage. There was a reduction in the concentration of $\mathrm{Ni}$ and $\mathrm{Cd}$ in all three stages as the wastewater came into contact with fresh biomass. From an initial concentration of $100 \mathrm{ppm}$, the final metal ion concentrations in solution were between 15 and $25 \mathrm{ppm}$ for $R$. bambusa and 50 to $55 \mathrm{ppm}$ for $B$. vulgaris. In a real life situation, the biomass will accumulate these metals, which will become toxic to the plants over time. 


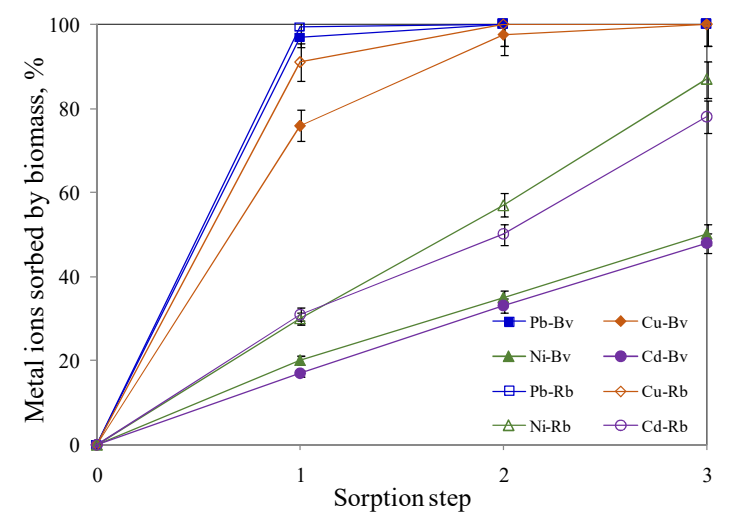

Fig. 9 Three-stage Sorption of $\mathrm{Pb}, \mathrm{Cu}, \mathrm{Ni}$ and $\mathrm{Cd}$ by Live Plants of $B$. vulgaris and $R$. bambusa. Initial Metal Ion and Biomass Concentrations were 100 ppm and $500 \mathrm{~g}$ Respectively

Comparing the mass of dry biomass against the volume of solution it came into contact with, the dry biomass sorbed more metal ions per unit weight of biomass than the live version. However, for applications on metal ion sequestration in natural environments, live biomass may be much easier to apply.

Sorption of metal ions by these plants may have public health implications. Juice from $R$. bambusa is tapped and drank locally as palm wine but $B$. vulgaris is not used for food. Further studies are required to know the part of the $R$. bambusa tree where these metal ions are stored and whether there is the potential for the metal ions to contaminate the palm wine produced. There is ongoing work to using real wastewater which contains other components to evaluate the performance of the biosorbents.

\section{Conclusions}

This study was conducted to investigate the sorption of cadmium, lead, copper and nickel using $B$. vulgaris and $R$. bambusa. Some of the functional groups on the biomass were the $\mathrm{OH}, \mathrm{C}=\mathrm{O}$ and $\mathrm{COOH}$ and $R$. bambusa appeared to have more pronounced groups than $B$. vulgaris. These functional groups interact with and sequester the metal ions.

The variables tested were contact time, biomass concentration and initial metal ion concentration. The metal ion concentration tested was in the range 10 to $100 \mathrm{ppm}$. From the study, it can be concluded that both materials have the potential to sorb the metal ions considered, with the highest removal efficiency and affinity towards lead. Maximum sorption values of over $95 \% \mathrm{Cu}$ and $\mathrm{Pb}$ were achieved by biomass derived from roots of $B$. vulgaris and $R$. bambusa. Sorption of $\mathrm{Cd}$ and $\mathrm{Ni}$ were lower at about $40 \%$.
The 3-stage sorption process helped to achieve $99.5 \%$ sorption of $\mathrm{Cu}$ and $\mathrm{Pb}$ using both biomasses. For $\mathrm{Cd}$ and $\mathrm{Ni}, 50 \%$ sorption was achieved with $B$. vulgaris and about $80 \%$ with $R$. bambusa. In all cases $R$. bambusa showed higher sorption capacities than B. vulgaris and this may be attributed to the more prominent functional groups which are known to interact with and capture metal ions. These plants may thus be grown extensively in areas where inhabitants do not have access to pipe-borne water, and surface waters containing these metal ions are used for drinking. In the long-term, the best strategy is to toughen up the pollution prevention measures and apply catchment management techniques to prevent metal pollution of water bodies.

\section{References}

Ahluwalia, S. S., Goyal, D. (2007), "Microbial and plant derived biomass for removal of heavy metals from wastewater", Bioresource Technology 98, pp. 2243-2257.

Amankwah, R. K. and Yen, W. T. (2005), "Biosorption of $\mathrm{Pb}^{2+}$ and $\mathrm{Cu}^{2+}$ Ions from a Binary Metal System by Steptomyces viridosporus", Ghana Mining Journal, Vol. 8, pp. 1 - 5.

Anon. (2010), "E-waste management: overview, United Nations environment programme", http://www.unep.fr/scp/waste/ewm/, Accessed December 10, 2013.

Areco, M. M., Hanela, S., Duran, J., dos Santos Afonso, M. (2012), "Biosorption of $\mathrm{Cu}(\mathrm{II})$, $\mathrm{Zn}(\mathrm{II}), \mathrm{Cd}(\mathrm{II})$ and $\mathrm{Pb}(\mathrm{II})$ by dead biomasses of green alga Ulva lactuca and the development of a sustainable matrix for adsorption Implementation", Journal of Hazardous Materials 213-214, pp. 123-132.

Asamoah, R. K., Ofori-Sarpong, G. and Amankwah, R. K. (2012), "Biosorption of heavy metals from waste water using Bambusa vulgaris (bamboo)", Proceedings of the $2^{\text {nd }}$ UMaT Biennial International Mining and Mineral Conference, pp. 56-61

Asante, K. A., Agusa, T., Biney, C. A., Agyekum, W. A., Bello, M., Otsuka, M., Itai, T., Takahashi, S. and Tanabe, S. (2012), "Multi-trace element levels and arsenic speciation in urine of e-waste recycling workers from Agbogbloshie, Accra in Ghana", Science of the Total Environment 424, pp. 63-73.

Bayo, J., Angosto, J.M. and Gomez-Lopez, M.D. (2009), "Ecotoxicological screening of reclaimed disinfected wastewater by Vibrio fischeri bioassay after a chlorination-dechlorination process", Journal of Hazardous Materials, 172, pp. 166-171.

Boeriu, C. G., Bravo, D., Gosselink, R. J. A. and van Dam, J. E. G. (2004), "Characterisation of structure-dependent functional properties of lignin with infrared spectroscopy", Industrial Crops and Products 20, pp. 205-218. 
Chen, J. P. and Yiacaumi, S. (1997), "Biosorption of Metal Ions from Aqueous Solutions", Separation Science and Technology, Vol. 32 (1-4), pp. 5169.

Davis, A.T., Volesky, B. and Alfonso, M. (2003), "A review of the biochemistry of heavy metal biosorption by brown algae", Water Research 37, pp. 4311-4330.

Ehrlich, H. L. (1997), "Microbes and Metals", Applied Microbiology and Biotechnology, Vol. 48, pp. 687-692.

Ehrlich, H. L. and Brierley, C. L. (eds.) (1990), "Microbial Mineral Recovery", McGraw-Hill, New York, pp. 303-324.

Faix, O. (1992), "Fourier transformed infrared spectroscopy", In: Lin, S.Y., Dence, C.W. (eds.), Methods in Lignin Chemistry. Springer-Verlag, Berlin-Heidelberg, pp. 400-464.

Fortin, J. (2013), "Mobile Phone Usage in Africa may Actually Worsen Violent Conflicts", http://www.ibtimes.com

Fourest, E. and Roux, J. C. (1992), "Heavy metal Biosorption by Fungal Mycelial by-products. Mechanism and Influence of $\mathrm{pH}$ ", Applied Microbiology and Biotechnology, Vol. 37, pp. 399-403.

Fourest, E. and Volesky, B. (1996), "Contribution of Sulphonate groups and Alginate to Heavy Metal Biosorption by the dry Biomass of Sargassum fluitants", Environmental Science and Technology, Vol. 30, pp. 277-302.

Fu, F. and Wang, Q. (2011), "Removal of heavy metal ions from wastewaters: a review", $J$. Environ. Manage. 92, pp. 407-418.

Glazer, A. N. and Nikaido, H. (1995), "Microbial Biotechnology: Fundamentals of Applied Microbiology", Freeman and Co., U.S.A. pp. 4987.

Gupta, V.K. and Ali, I. (2004), "Removal of lead and chromium from wastewater using bagasse fly ash - a sugar industry waste", Journal of Colloid and Interface Science, 271, pp. 321-328.

Hawari, A.H. and Mulligan, C.N. (2006), "Biosorption of lead (II), cadmium (II), copper (II) and nickel (II) by anaerobic granular biomass", Bioresource Technology, 97, pp. 692700 .

Ibrahim, W. M. (2011), "Biosorption of heavy metal ions from aqueous solution by red macroalgae", Journal of Hazardous Materials 192, pp. 18271835.

Itai, T., Otsuka, M., Asante, K. A. and Muto, M., Opoku-Ankomah, Y., Ansa-Asare, O. D. and Tanabe, S. (2014), "Variation and distribution of metals and metalloids in soil/ash mixtures from Agbogbloshie e-waste recycling site in Accra, Ghana", Science of the Total Environment, 470471, pp. 707-716.

Iyer, A., Mody, K. Jha, B. (2005) "Biosorption of heavy metals by a marine bacterium", Marine Pollution Bulletin 50, pp. 340-343.
Kochi, E. (2012), "How the Future of Mobile lies in the Developing World", http://tech crunch.com/2012/05/27/mobile-developingworld, Accessed June 30, 2014.

Man, M., Naidu, R., Wong. M. H. (2013), "Persistent toxic substances released from uncontrolled e-waste recycling and actions for the future", Science of the Total Environment 463-464, pp. 1133-1137.

Oteng-Ababio, M. (2012), "When necessity begets ingenuity: scavenging for survival in a globalizing city", African Studies Quarterly, 13(1and2), pp. 1-21.

Oteng-Ababio, M., Amankwaa, E. F. and Chama, M. A. (2014), "The local contours of scavenging for e-waste and higher-valued constituent parts in Accra, Ghana", Habitat International, 43, 163171.

Park, S., Kang, D., Kim, Y., Lee, S. M., Chung, Y. and Sung, K. (2011), "Biosorption and growth inhibition of wetland plants in water contaminated with a mixture of arsenic and heavy metals", Engineering Life Sciences, 11:8493.

Terazono A., Murakami S., Abe N., Inanc B., Moriguchi Y., Sakai S. (2006), "Current status and research on E-waste issues in Asia", Journal of Material Cycles and Waste Management, 8, pp. 1-12.

Tsezos, M. (2001), "Biosorption of Metals; The Experience Accumulated and the outlook for Technology Development", Hydrometallurgy, Vol. 59, pp. 21-243.

Volesky, B. (1990), "Biosorption and Biosorbents, In: Biosorption of Heavy Metals", Volesky, B., (Ed.), Boca Raton, FL: CRC Press, Inc., pp. 3-6.

Volesky, B. (2001), "Detoxification of Metal Bearing Effluents: Biosorption for the Next Century", Hydrometallurgy, Vol 59 pp. 302-216.

Volesky, B. and Holan, Z. R. (1995), "Biosorption of Heavy Metals", Proceedings of Biotechnology Program, Vol. 11, No. 3, pp. 235 - 250.

Volesky, B. (1994), "Advances in biosorption of metals: selection of biomass types", FEMS Microbiology Reviews 14, pp. 291-302.

Yong, R. N., Mulligan, C. N. and Fukue, M. (2006) "Technology and Engineering", Google Book, Accessed January 2, 2014.

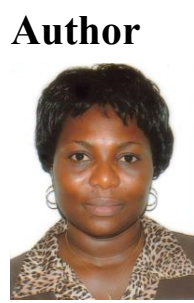

Grace Ofori-Sarpong is an Associate Professor of Minerals Engineering at the University of Mines and Technology, Tarkwa. She holds a Bachelor of Science Degree in Metallurgical Engineering and a Master of Science Degree in Environmental Resources Management, both from the Kwame Nkrumah University of Science and Technology, KNUST, Kumasi, Ghana. She also has a PhD in Energy and Minerals Engineering from the Pennsylvania State University, USA. She is a member of the Graduate Women in Science (GWIS), USA, Society for Mining, Metallurgy and Exploration (SME), USA, Society of Petroleum Engineering (SPE), USA, Member, International Women in Mining Community (WIM), 
UK, and the Founder of Ladies in Mining and Allied Professions in Ghana (LiMAP-Gh). Her areas of research interests include microbial-mineral interaction, recovery of precious metals, microwave processing, water quality monitoring and mine waste management.

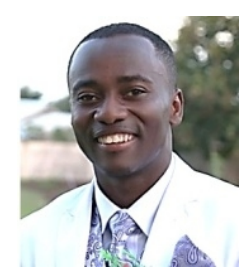

Richmond Komla Asamoah obtained his BSc (Hons) degree in Mineral Engineering from University of Mines and Technology (UMaT), Tarkwa, Ghana. He is currently pursuing $\mathrm{PhD}$ studies in the University of South Australia under Future Industries Institute (FII). His research interests include geometallurgy, gold extraction and environmental biotechnology.

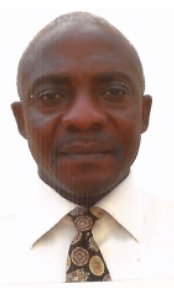

Joseph J. K. Gordon is a Lecturer at the University of Mines and Technology (UMaT) Tarkwa. He holds MPhil and BSc degrees in Metallurgical Engineering from Kwame Nkrumah University of Science and Technology Kumasi. His research activities are in Biohydrometallurgy, Mine Waste Processing and characterization. $\mathrm{He}$ is a member of the American Society for Quality (ASQ).

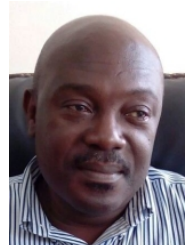

Richard K Amankwah is a Professor of Minerals Engineering at the University of Mines and Technology (UMaT), Tarkwa, Ghana. He holds MPhil and BSc degrees in Metallurgical Engineering from Kwame Nkrumah University of Science and Technology Kumasi and a PhD from Queen's University, Kingston, Canada. He is a membe of the Ghana Institution of Engineers (GhIE) and Society for Mining, Metallurgical and Exploration (SME). His research interests include gold beneficiation, geometallurgy, water quality management, microwave processing of minerals, small-scale mining, medical geology, microbial mineral recovery and environmental biotechnology. 